\title{
Dependence of Spontaneous Electrical Activity and Basal Prolactin Release on Nonselective Cation Channels in Pituitary Lactotrophs
}

\author{
M. KUČKA ${ }^{1}$, K. KRETSCHMANNOVÁ ${ }^{1}$, S. S. STOJILKOVIC ${ }^{1}$, H. ZEMKOVÁ ${ }^{1,2}$, \\ M. TOMIĆ ${ }^{1}$ \\ ${ }^{1}$ Section on Cellular Signaling, PDN, NICHD, National Institutes of Health, Bethesda, USA, \\ ${ }^{2}$ Department of Cellular and Molecular Neuroendocrinology, Institute of Physiology of the \\ Academy of Sciences of the Czech Republic, Prague, Czech Republic
}

Received December 12, 2011

Accepted February 16, 2012

On-line April 5, 2012

\section{Summary}

All secretory anterior pituitary cells fire action potentials spontaneously and exhibit a high resting cation conductance, but the channels involved in the background permeability have not been identified. In cultured lactotrophs and immortalized $\mathrm{GH}_{3}$ cells, replacement of extracellular $\mathrm{Na}^{+}$with large organic cations, but not blockade of voltage-gated $\mathrm{Na}^{+}$influx, led to an instantaneous hyperpolarization of cell membranes that was associated with a cessation of spontaneous firing. When cells were clamped at $-50 \mathrm{mV}$, which was close to the resting membrane potential in these cells, replacement of bath $\mathrm{Na}^{+}$with organic cations resulted in an outward-like current, reflecting an inhibition of the inward holding membrane current and indicating loss of a background-depolarizing conductance. Quantitative RTPCR analysis revealed the high expression of mRNA transcripts for TRPC1 and much lower expression of TRPC6 in both lactotrophs and $\mathrm{GH}_{3}$ cells. Very low expression of TRPC3, TRPC4, and TRPC5 mRNA transcripts were also present in pituitary but not $\mathrm{GH}_{3}$ cells. 2-APB and SKF-96365, relatively selective blockers of TRPC channels, inhibited electrical activity, $\mathrm{Ca}^{2+}$ influx and prolactin release in a concentration-dependent manner. $\mathrm{Gd}^{3+}$, a common $\mathrm{Ca}^{2+}$ channel blocker, and flufenamic acid, an inhibitor of non-selective cation channels, also inhibited electrical activity, $\mathrm{Ca}^{2+}$ influx and prolactin release. These results indicate that nonselective cation channels, presumably belonging to the TRPC family, contribute to the background depolarizing conductance and firing of action potentials with consequent contribution to $\mathrm{Ca}^{2+}$ influx and hormone release in lactotrophs and $\mathrm{GH}_{3}$ cells.

\section{Key words}

TRPC channels $\bullet \mathrm{GH}_{3}$ cells $\bullet$ Calcium influx • Action potentials • Resting membrane potential

\section{Corresponding author}

Hana Zemkova, Institute of Physiology, Academy of Sciences of the Czech Republic, v.v.i., Vídeňská 1083, 14220 Prague 4, Czech Republic. Fax: +42024106 2488. E-mail: zemkova@biomed.cas.cz

\section{Introduction}

The endocrine pituitary functions are carried out by corticotrophs secreting adrenocorticotrophic hormone, thyrotrophs secreting thyroid-stimulating hormone, somatotrophs secreting growth hormone, lactotrophs secreting prolactin (PRL), and gonadotrophs secreting luteinizing and follicle-stimulating hormones (Kelberman et al. 2009). The common characteristic of these cells, as well as of immortalized pituitary cells, is their spontaneous excitability. Firing of action potentials (APs) reflects the expression of numerous voltage-gated channels on the plasma membrane of these cells, including voltage-gated and tetrodotoxin (TTX)-sensitive $\mathrm{Na}^{+}\left(\mathrm{Na}_{\mathrm{v}}\right)$ channels, voltage-gated $\mathrm{Ca}^{2+}\left(\mathrm{Ca}_{\mathrm{v}}\right)$ channels, voltage-gated $\mathrm{K}^{+}$channels, calcium-regulated $\mathrm{K}^{+}$ channels, inwardly rectifying $\mathrm{K}^{+}$channels, purinergic P2X channels, and $\mathrm{GABA}_{\mathrm{A}}$ channels (Kwiecien and Hammond 1998, Stojilkovic et al. 2010). Spontaneous firing of APs in all pituitary cell types leads to the activation of $\mathrm{Ca}_{\mathrm{v}}$ channels and increased intracellular 
calcium ion concentration $\left(\left[\mathrm{Ca}^{2+}\right]_{\mathrm{i}}\right)$, with the amplitude of transients determined by the pattern of firing (Stojilkovic at al. 2005). The $\mathrm{T}$ - and $\mathrm{L}$-type $\mathrm{Ca}_{\mathrm{v}}$ channels play a role in spike depolarization, while voltage-gated $\mathrm{K}^{+}$channels and $\mathrm{Ca}^{2+}$-controlled $\mathrm{K}^{+}$channels are responsible for plateau bursting and repolarization of cells (Van Goor et al. 2001a, Tsaneva-Atanasova et al. 2007).

The physiological significance of electrical activity in lactotrophs is well established. These cells in vitro release PRL in the absence of external stimuli, and such secretion is termed basal or spontaneous release (Freeman et al. 2000). High PRL release is also observed in animals bearing ectopic pituitary grafts (Maric et al. 1982). In both cases, spontaneous APs and the associated $\mathrm{Ca}^{2+}$ influx account for high steady-state PRL release and any maneuver leading to silencing of electrical activity also abolishes $\mathrm{Ca}^{2+}$ influx and basal PRL release (Van Goor et al. 2001a). In vivo, spontaneous electrical activity and PRL release are controlled by hypothalamic dopamine, acting through dopamine D2 receptors. Activation of these receptors leads to silencing of electrical activity through activation of inwardly rectifying $\mathrm{K}^{+}$channels and inhibition of $\mathrm{Ca}_{\mathrm{v}}$ channels (Missale et al. 1998). $\mathrm{GH}_{3}$ cells, an established immortalized cell line derived from a rat anterior pituitary tumor, maintain pituitary-specific behavior in culture by secreting PRL and growth hormone (Cronin et al. 1980). These cells are spontaneously electrically active with high amplitude APs and often serve as a convenient cell model in studying electrophysiological properties of lactotrophs and somatotrophs (Lo et al. 2001).

Channels contributing to the spike depolarization and repolarization in spontaneously firing cells have been identified (Stojilkovic et al. 2010). In contrast, very little is known about channels controlling resting membrane potential and initiation of firing of APs. Resting membrane potential in these cells is between -50 and $-60 \mathrm{mV}$, positive to the equilibrium potassium potential, indicating the presence of depolarizing conductance. TTX-sensitive $\mathrm{Na}_{\mathrm{v}}$ channels are expressed in pituitary cells, but do not play important role in control of resting membrane potential and spike depolarization in lactotrophs in vitro (Van Goor et al. 2001b). A TTXinsensitive background $\mathrm{Na}^{+}\left(\mathrm{Na}_{\mathrm{b}}\right)$ conductance was also identified in pituitary lactotrophs and $\mathrm{GH}_{3}$ immortalized cells as necessary for spontaneous depolarization and PRL release (Simasko 1994, Sankaranarayanan and Simasko 1996). However, the nature of these channels and the mechanism for their activation has not been identified.

Here we show that the abolition of $\mathrm{Na}_{b}$ conductance by substituting extracellular $\mathrm{Na}^{+}$with large organic cations leads to a rapid and reversible hyperpolarization of the plasma membrane and inhibition of firing of APs, $\mathrm{Ca}^{2+}$ influx and PRL secretion. Our results further indicate that this conductance takes place through non-selective cation channels, presumably the transient receptor potential - classic (TRPC) subfamily of these channels, which have been identified in pituitary cells using quantitative real-time PCR. TRPC channels conduct both $\mathrm{Na}^{+}$and $\mathrm{Ca}^{2+}$, are voltage independent and their role in spontaneous and receptor controlled electrical activity and calcium signaling has been indicated in other excitable cells (Clapham et al. 2005).

\section{Methods}

Animals and cell cultures

Experiments were performed on anterior pituitary cells from normal postpubertal female Sprague Dawley rats obtained from Taconic Farm (Germantown, $\mathrm{MD})$. Euthanasia was performed by asphyxiation with $\mathrm{CO}_{2}$ and the anterior pituitary glands were removed after decapitation. Experiments were approved by the NICHD Animal Care and Use Committee. Anterior pituitary cells were mechanically dispersed after treatment with trypsin and cultured as mixed cells or enriched lactotrophs in medium 199 containing Earle's salts, sodium bicarbonate, $10 \%$ heat-inactivated horse serum, penicillin (100 units/ml), and streptomycin $(100 \mu \mathrm{g} / \mathrm{ml})$. A twostage Percoll discontinuous density gradient procedure was used to obtain enriched lactotrophs (Lussier et al. 1991). Further identification of lactotrophs in single cell studies was achieved by the addition of dopamine (Tocris Bioscience, Ellisville, MO) and TRH (Bachem, Torrance, CA). Immortalized $\mathrm{GH}_{3}$ pituitary cells were cultured in Ham's F12K medium supplemented with $15 \%$ heatinactivated horse serum, $2.5 \%$ fetal bovine serum, and gentamicin $(100 \mu \mathrm{g} / \mathrm{ml})$.

\section{Electrophysiological measurements}

Pituitary cells were plated on poly-L-lysine coated cover slips (15 mm diameter) in densities of 100,000 primary cells per cover slip and 10,000 immortalized cells per cover slip and cultured for 1-3 days prior to recording. All recordings were performed at room temperature using Axopatch 200B amplifier (Molecular Devices, Union City, CA). The amphotericine 
perforated patch-clamp technique was used to record membrane potentials and whole cell currents. Cells were continuously perfused with an extracellular solution containing (in mM): $145 \mathrm{NaCl}, 5 \mathrm{KCl}, 2 \mathrm{CaCl}_{2}, 1 \mathrm{MgCl}_{2}$, 10 4-(2-hydroxyethyl)piperazine-1-ethanesulfonic acid (HEPES), and 10 glucose ( $\mathrm{pH}$ 7.4). For $\mathrm{Na}^{+}$-free experiments, $\mathrm{NaCl}$ was replaced in 1:1 ratio by $\mathrm{N}$-methylD-glucamine (NMDG), tetramethylammonium (TMA), or choline chloride ( $\mathrm{pH}$ 7.4). Patch pipettes were pulled from borosilicate glass (World Precision Instruments, Sarasota, FL) and heat polished to a tip resistance of 5-7 M . Pipette solution contained (in $\mathrm{mM}$ ): $90 \mathrm{~K}$ aspartate, $50 \mathrm{KCl}, 3 \mathrm{MgCl}_{2}$ and 10 HEPES (pH 7.2). Prior to measurement, amphotericine $\mathrm{B}$ was added to the pipette solution from a stock solution to obtain a final concentration of $200 \mu \mathrm{g} / \mathrm{ml}$. Recordings started when series resistance dropped below $100 \mathrm{M} \Omega$ for currentclamp or below $40 \mathrm{M} \Omega$ for voltage-clamp recordings. Series resistance was compensated to more than $60 \%$. Drugs dissolved to a final concentration in extracellular solutions were delivered to the recording chamber by a gravity-driven microperfusion system RSC-200 (BioLogic USA, Knoxville, TN).

\section{Single cell intracellular calcium measurements}

For measurements of $\left[\mathrm{Ca}^{2+}\right]_{i}$, cells were incubated in Krebs Ringer buffer with $2 \mu \mathrm{M}$ Fura-2 AM (Invitrogen, Carlsbad, CA) at room temperature for $60 \mathrm{~min}$. For $\mathrm{Na}^{+}$-free experiments, $\mathrm{NaCl}$ was replaced by NMDG and $\mathrm{pH}$ was brought to 7.4 by adding $\mathrm{HCl}$. Coverslips with cells were then washed with KrebsRinger buffer and mounted on the stage of an ObserverD1 microscope (Carl Zeiss, Oberkochen, Germany) attached to an ORCA-ER camera (Hamamatsu Photonics, Hamamatsu City, Japan) and a Lambda 10-B filter wheel (Sutter, Novato, CA) with 340 and $380 \mathrm{~nm}$ excitation filters (Carl Zeiss, Oberkochen, Germany). Hardware control and image analysis was performed using Metafluor software (Molecular Devices, Downingtown, PA). Cells were examined under an oil immersion objective during exposure to alternating 340- and 380-nm light beams, and the intensity of light emission at $520 \mathrm{~nm}$ was measured. The ratio of light intensities, $\mathrm{F}_{340} / \mathrm{F}_{380}$, which reflects changes in $\left[\mathrm{Ca}^{2+}\right]_{\mathrm{i}}$, was followed in several single cells simultaneously at the rate of one point per second.

\section{Prolactin secretion}

Hormone secretion was monitored using cell column perifusion experiments. Briefly, $1.5 \times 10^{7}$ cells were incubated with preswollen cytodex-1 beads in $60-\mathrm{mm}$ petri dishes for $18 \mathrm{~h}$. The beads were then transferred to $0.5-\mathrm{ml}$ chambers and perifused with Hanks' M199 containing $25 \mathrm{mM}$ HEPES, $0.1 \%$ BSA, and penicillin $(100 \mathrm{U} / \mathrm{ml}) /$ streptomycin $(100 \mu \mathrm{g} / \mathrm{ml})$ at $37{ }^{\circ} \mathrm{C}$ for $2.5 \mathrm{~h}$ at a flow rate of $0.8 \mathrm{ml} / \mathrm{min}$ to establish stable basal secretion. Fractions were collected in 1-min intervals and their PRL content was later determined using radioimmunoassay. Primary antibody and standard for PRL assay were purchased from the National Pituitary Agency and Dr. A. F. Parlow (Harbor-UCLA Medical Center, Torrance, CA). $\left[{ }^{125} \mathrm{I}\right] \mathrm{PRL}$ was purchased from PerkinElmer Life Sciences (Boston, MA).

\section{$R T$-PCR analysis}

Total RNA from the primary pituitary cells was extracted using the RNeasy Mini Kit. Subsequently, $1 \mu \mathrm{g}$ of total RNA was treated with DNAse I and reverse transcribed with SuperScript III First Strand Synthesis SuperMix for qRT-PCR (all from Invitrogen, Carlsbad, CA). Quantitative RT-PCR was performed using predesigned Taq-Man Gene Expression Assays (Applied Biosystems) with LightCycler ${ }^{\circledR}$ TaqMan ${ }^{\circledR}$ Master mix and LightCycler 2.0 Real-time PCR system (Roche Applied Science). Gene expression levels of the target genes were determined by the comparative $2^{\wedge}$ (-delta delta $\mathrm{C}(\mathrm{T})$ ) quantification method using GAPDH as a reference gene, where (delta delta $\mathrm{C}(\mathrm{T}))=(\mathrm{CT}$, target $-\mathrm{CT}$, reference)sample $-(\mathrm{CT}$, target $-\mathrm{CT}$, reference) control. The Applied Biosystems pre-designed Taq-Man Gene Expression Assays were used: TRPC1-Rn00585625_m1; TRPC2-Rn00575304_m1; TRPC3-Rn00572928_m1; TRPC4-Rn00584835_m1; TRPC5-Rn00590142_m1; TRPC6-Rn00677564_m1; TRPC7-Rn01448763_m1; GAPDH-Rn01462662_g1.

\section{Results}

Dependence of electrical activity and PRL release on the background $\mathrm{Na}^{+}$conductance

To determine the role of $\mathrm{Na}_{b}$ conductance in resting membrane potential and spontaneous electrical activity of pituitary cells, we first examined the effect of $\mathrm{Na}^{+}$removal from extracellular solution. We used lactotrophs and $\mathrm{GH}_{3}$ cells that tend to fire APs spontaneously (Fig. 1A and C). However, the fraction of active cells is lower in lactotrophs than in $\mathrm{GH}_{3}$ cells: about $60 \%$ and $90 \%$, respectively. TTX, a $\mathrm{Na}_{\mathrm{v}}$ channel 
blocker, was ineffective in abolishing spontaneous electrical activity (Fig. 1C) in concentrations up to $10 \mu \mathrm{M}$. In contrast, replacement of extracellular $\mathrm{Na}^{+}$with NMDG led to an instantaneous hyperpolarization of cell membranes both in lactotrophs $(-15.1 \pm 2.2 \mathrm{mV} ; \mathrm{n}=6)$ and $\mathrm{GH}_{3}$ cells $(-28.3 \pm 7.2 \mathrm{mV} ; \mathrm{n}=10)$. The hyperpolarization was associated with a cessation of spontaneous firing of APs (Fig. 1A). Once the cells were returned to $\mathrm{Na}^{+}$- containing physiological buffer, the spontaneous electrical activity resumed. We also frequently observed an increase in the firing frequency during the initial period of the recovery phase (Fig. 1A), which could indicate that the level of $\left[\mathrm{Ca}^{2+}\right]_{i}$ determines the frequency of spontaneous firing of APs. These experiments show that basal sodium conductance controls resting membrane potential and electrical activity in pituitary cells.
A

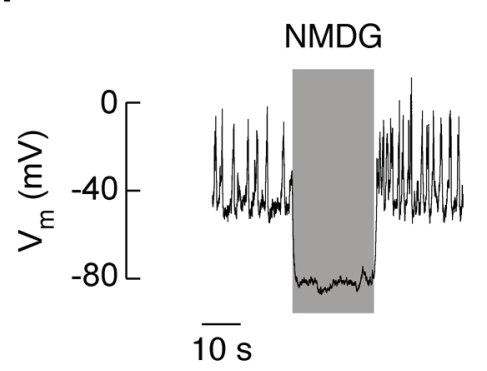

B

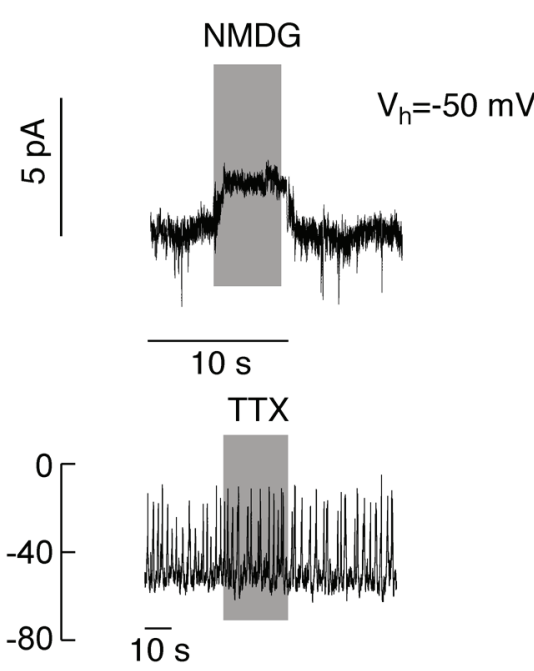

$\mathrm{GH}_{3}$ CELLS

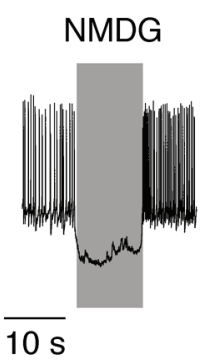

NMDG
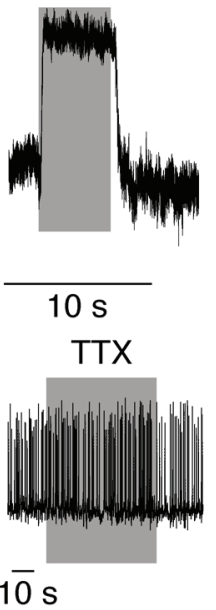

D

LACTOTROPHS

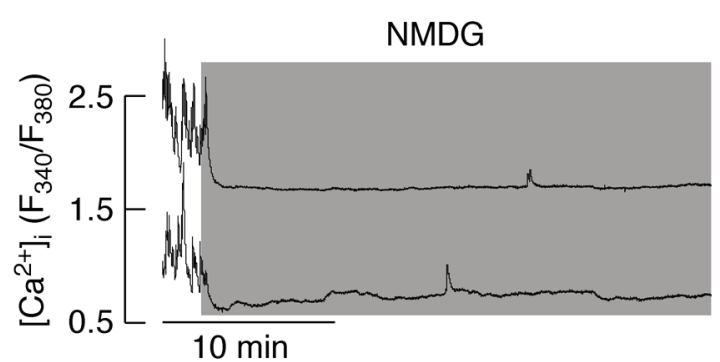

E
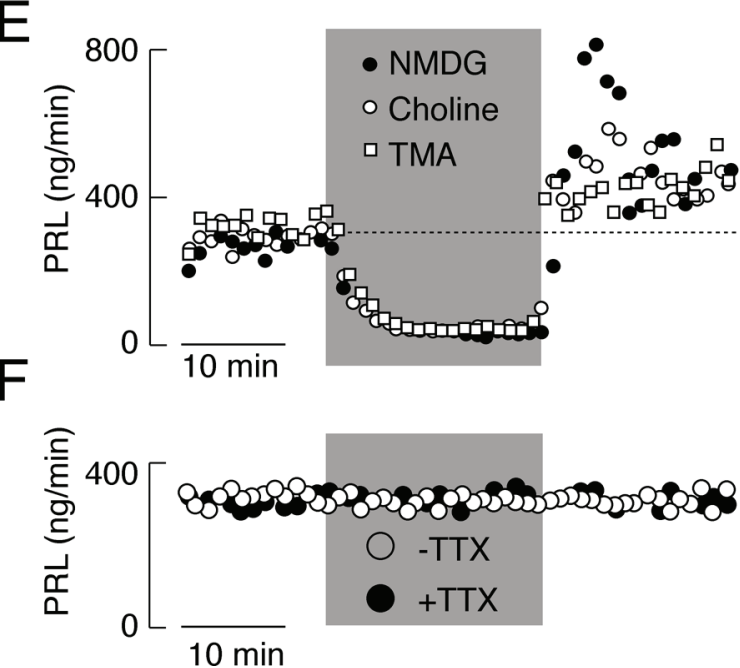

Fig. 1. Spontaneous electrical activity, calcium influx and basal prolactin (PRL) release of pituitary cells depend on a background $\mathrm{Na}^{+}$ conductance. A and $\mathbf{B}$, Effects of complete replacement of extracellular $\mathrm{Na}^{+}$with NMDG on electrical activity (A) and whole cell current (B) in lactotrophs (left panels) and $\mathrm{GH}_{3}$ cells (right panels). Note the increased firing frequency after return to normal $\mathrm{Na}^{+}$-containing bath buffer. $V_{h}$, holding potential. C, The lack of effects of $1 \mu \mathrm{M} T \mathrm{TX}$, a $\mathrm{Na}_{\mathrm{v}}$ channel blocker, on membrane potential $\left(\mathrm{V}_{\mathrm{m}}\right)$ and spontaneous firing of APs in lactotrophs (left panel) and $\mathrm{GH}_{3}$ cells (right panel). D, Effect of complete replacement of bath $\mathrm{Na}^{+}$with NMDG on spontaneous calcium transients in lactotrophs. In this and following figures, data shown are representative of at least 5 recordings. Similar effects of replacement of bath $\mathrm{Na}^{+}$with NMDG were observed in other pituitary cell types. E, Effect of complete replacement of bath $\mathrm{Na}^{+}$with NMDG, TMA and choline chloride on basal PRL release in perifused pituitary cells. In parallel to electrical activity (Fig. 1A, left), notice the transient increase in PRL release after return of $\mathrm{Na}^{+}$containing buffer. $\mathbf{F}$, The lack of effect of TTX on basal PRL release. Gray areas indicate duration of treatments.

In further experiments we asked whether calcium influx and hormone secretion are regulated by $\mathrm{Na}_{\mathrm{b}}$ conductance. We clamped cells at $-50 \mathrm{mV}$, a physiologically relevant voltage because the resting potentials in these cells were close to that value (Fig. 1A and 1C). In both cell types, TTX had no effect on holding current (data not shown), while complete replacement of extracellular $\mathrm{Na}^{+}$with NMDG caused a shift in the baseline, with the appearance of an outward current (Fig. 1B). A decrease in the noise of recording during NMDG application suggested that the shift in the baseline was due to a closure of cation channels and loss of a background depolarizing conductance. The amplitude of this outward-like current was $2.1 \pm 0.3 \mathrm{pA}(\mathrm{n}=7)$ in lactotrophs and $9.9 \pm 1.7 \mathrm{pA}(\mathrm{n}=13)$ in $\mathrm{GH}_{3}$ cells. It was not abolished by the blockade of L-type $\mathrm{Ca}_{\mathrm{v}}$ channels 
with nimodipine or by the inhibition of hyperpolarization-activated $\mathrm{HCN}$ channels with $1 \mathrm{mM}$ $\mathrm{Cs}^{+}$(data not shown). The same qualitative effects on membrane voltage and current were observed by substituting bath $\mathrm{Na}^{+}$with other large organic cations, including TMA and choline (data not shown).

Removal of bath $\mathrm{Na}^{+}$also led to cessation of calcium transients and rapid decrease in $\left[\mathrm{Ca}^{2+}\right]_{i}$ basal levels (Fig. 1D). Figures $1 \mathrm{E}$ and $1 \mathrm{~F}$ show that basal PRL release from primary rat pituitary cells is high, indicating that spontaneous $\left[\mathrm{Ca}^{2+}\right]_{\mathrm{i}}$ transients are sufficient to trigger hormone secretion. A transient replacement of $\mathrm{Na}^{+}$with large organic cations abolished such elevated basal PRL release by perifused pituitary cells (Fig. 1E), while TTX had no effect on hormone secretion (Fig. 1F). Thus, spontaneous firing of APs and accompanied $\left[\mathrm{Ca}^{2+}\right]_{i}$ transients in lactotrophs and $\mathrm{GH}_{3}$ cells depends on TTXinsensitive $\mathrm{Na}_{\mathrm{b}}$ conductance, and such electrical activity is critical for basal PRL release.
A

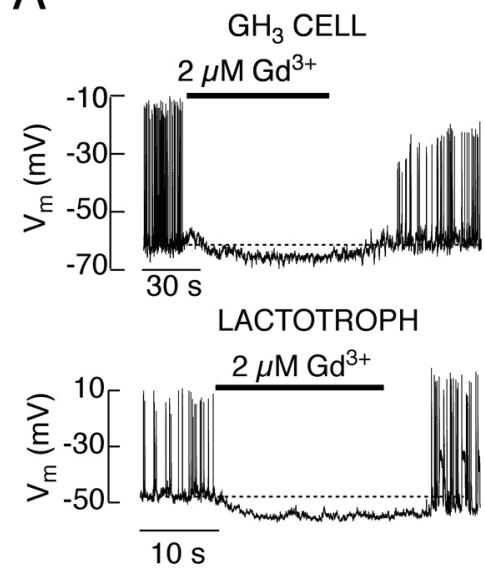

B

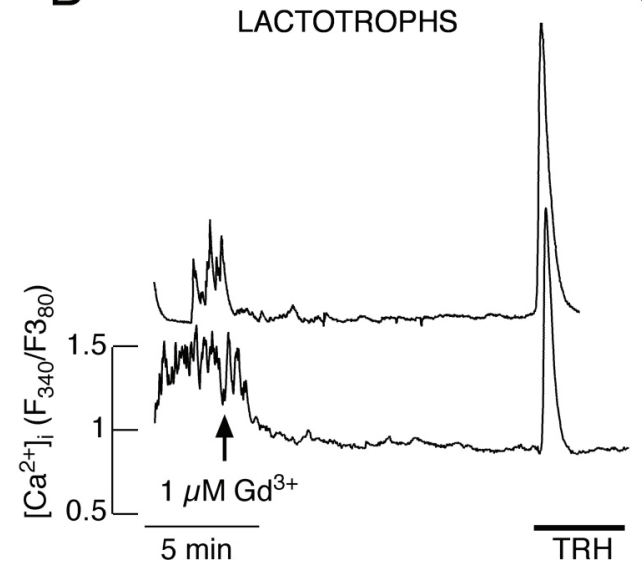

C

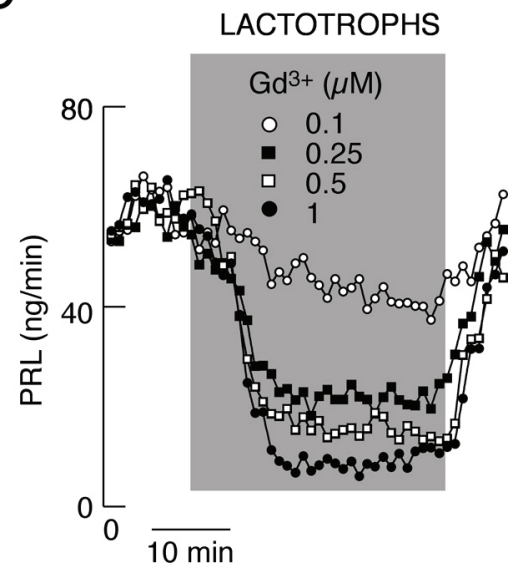

Fig. 2. Effects of $\mathrm{Gd}^{3+}$, a non-specific blocker of calcium-conducting channels, on electrical activity in $\mathrm{GH}_{3}$ cells and lactotrophs (A), calcium influx in lactotrophs (B) and PRL release in perifused pituitary cells $(\mathbf{C})$. Notice the $\mathrm{Gd}^{3+}$-induced hyperpolarization of the plasma membrane in $\mathrm{A}$.

A

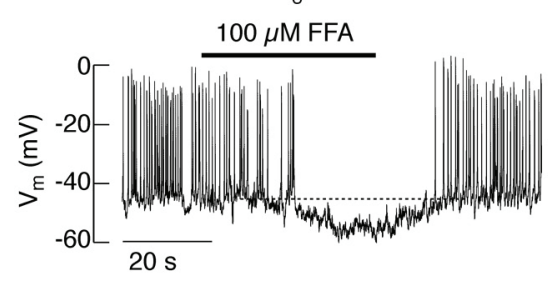

B

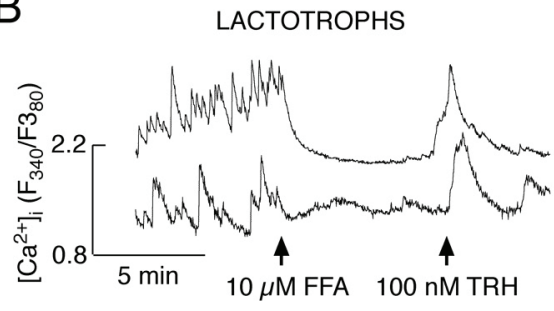

C

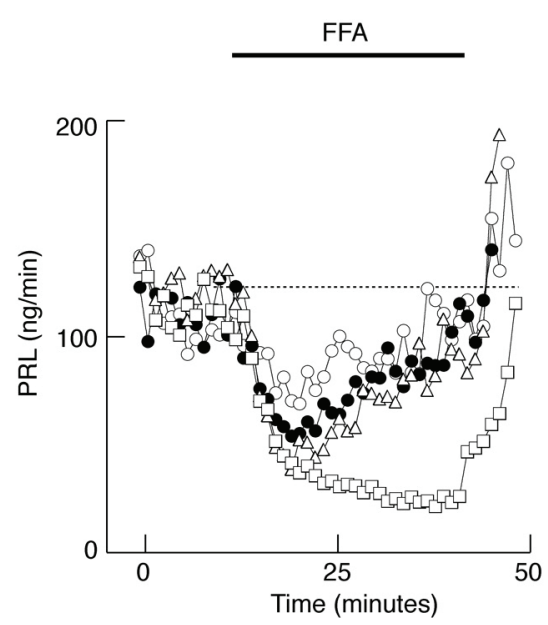

D
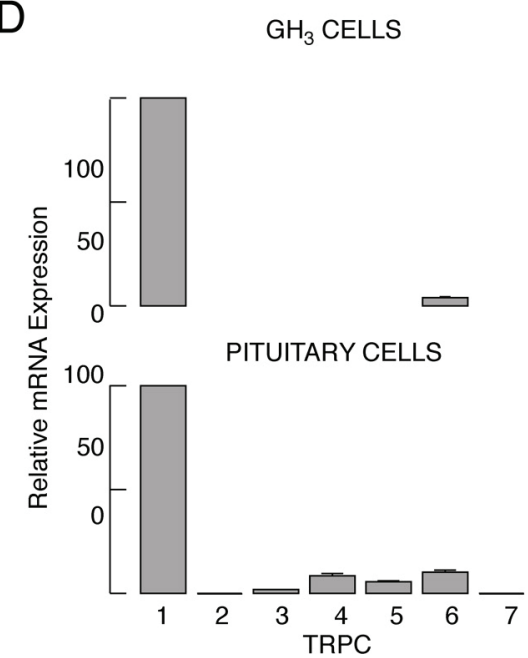

Fig. 3. Effects of flufenamic acid (FFA), a blocker of various non-selective cation channels, on electrical activity in $\mathrm{GH}_{3}$ cells $(\mathbf{A})$, calcium influx in lactotrophs (B) and PRL release in perifused pituitary cells (from top to bottom 25, 50, 75 and $100 \mu M)($ C). D, Quantitative RT-PCR analysis of TRPC-mRNA expression in $\mathrm{GH}_{3}$ cells (top). Data shown are mean \pm SEM values of six experiments, using TRPC1mRNA expression as $100 \%$. Results for pituitary cells (bottom panel) are derived from Tomic et al. 2011. Notice the FFA-induced hyperpolarization of the plasma membrane in $\mathrm{A}$. 
Dependence of electrical activity and PRL release on $\mathrm{Ca}^{2+}$ conductance

To resolve the identity of the channels contributing to $\mathrm{Na}_{b}$ conductance-dependent $\mathrm{Ca}^{2+}$ influx and PRL release, we first used $\mathrm{Gd}^{3+}$, an inhibitor of various $\mathrm{Ca}^{2+}$-conducting channels, including $\mathrm{Ca}_{\mathrm{v}}$ and TRPC channels (Clapham et al. 2005, Biagi and Enyeart 1990, Lacampagne et al. 1994). Electrophysiological experiments in single $\mathrm{GH}_{3}$ cells and lactotrophs showed that $\mathrm{Gd}^{3+}$ in $2 \mu \mathrm{M}$ concentration not only abolished firing of APs, but also hyperpolarized the cell membrane (Fig. 2A). However, this hyperpolarization was smaller than the one caused by removal of bath $\mathrm{Na}^{+}$(Fig. 1A). In single lactotrophs, addition of $\mathrm{GdCl}_{3}$ abolished spontaneous calcium transients (Fig. 2B) similarly as replacement of $\mathrm{Na}^{+}$with NMDG (Fig. 1D). In perifused pituitary cells, $\mathrm{Gd}^{3+}$ inhibited basal PRL release in a concentration-dependent manner, with an $\mathrm{IC}_{50}$ value of about $0.2 \mu \mathrm{M}$ (Fig. 2C). This raises the possibility that $\mathrm{Na}_{b}$ channels conduct $\mathrm{Ca}^{2+}$ in addition to $\mathrm{Na}^{+}$, i.e. that some of the non-selective cation channels account for or contribute to $\mathrm{Na}_{\mathrm{b}}$ conductance. Consistent with this hypothesis, flufenamic acid (FFA), a generic blocker of non-selective cation channels (Egorov et al. 2002, Ghamari-Langroudi and Bourque 2002), also abolished spontaneous firing of APs in $\mathrm{GH}_{3}$ cells, and hyperpolarized the cell membrane by $5-10 \mathrm{mV}$ (Fig. 3A). Furthermore, FFA inhibited spontaneous $\left[\mathrm{Ca}^{2+}\right]_{\mathrm{i}}$ transients in TRH-indentified lactotrophs (Fig. 3B) and basal PRL release in perifused pituitary cells (Fig. 3C). These physiological and pharmacological responses indicate that non-selective cation channels are involved in the background depolarization of pituitary lactotrophs and $\mathrm{GH}_{3}$ cells.

\section{Expression and contribution of TRPC channels to $\mathrm{Na}_{b}$ conductance}

In further work, we collected more evidence on expression and active involvement of TRPC subfamily of these channels in $\mathrm{GH}_{3}$ cells. These cells express TRPC1 and TRPC6 mRNA transcripts (Fig. 3D, top), whereas pituitary cells also express mRNA transcripts for TRPC2, TRPC3, TRPC4, TRPC5 and TRPC7 (Fig. 3D, bottom). SKF96365, a widely used and relatively specific inhibitor of TRPC channels (Clapham et al. 2005), inhibited the electrical activity in $\mathrm{GH}_{3}$ cells (data not shown). In lactotrophs, $10 \mu \mathrm{M}$ SKF96365 inhibited $\left[\mathrm{Ca}^{2+}\right]_{\mathrm{i}}$ transients (Fig. 4A), in some cells after a transient increase in $\left[\mathrm{Ca}^{2+}\right]_{\mathrm{i}}$ (data not shown). Consistent with these results, application of SKF96365 decreased PRL secretion from perifused pituitary cells in a concentration-dependent manner (Fig. 4B). 2-APB, another blocker of TRPC channels (Clapham et al. 2005), had similar effects on AP firing in $\mathrm{GH}_{3}$ cells (not shown) and basal PRL secretion in perifused pituitary cells (Fig. 4C). PRL secretion was inhibited in a concentration dependent manner with an $\mathrm{IC}_{50}$ value of $38 \mu \mathrm{M}$. These results suggest that TRPC channels contribute to $\mathrm{Na}_{b}$ conductance in lactotrophs and $\mathrm{GH}_{3}$ cells, and that their contribution is physiologically relevant.

A

B LACTOTROPHS PITUITARY CELLS

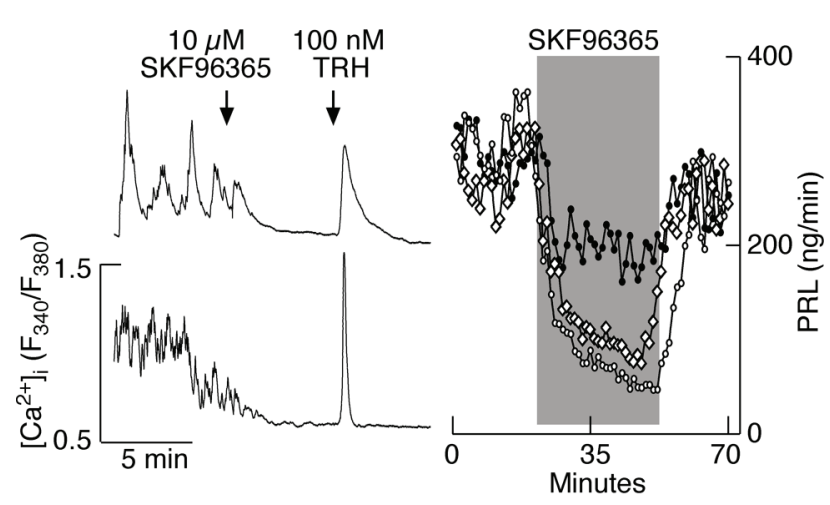

C PITUITARY CELLS

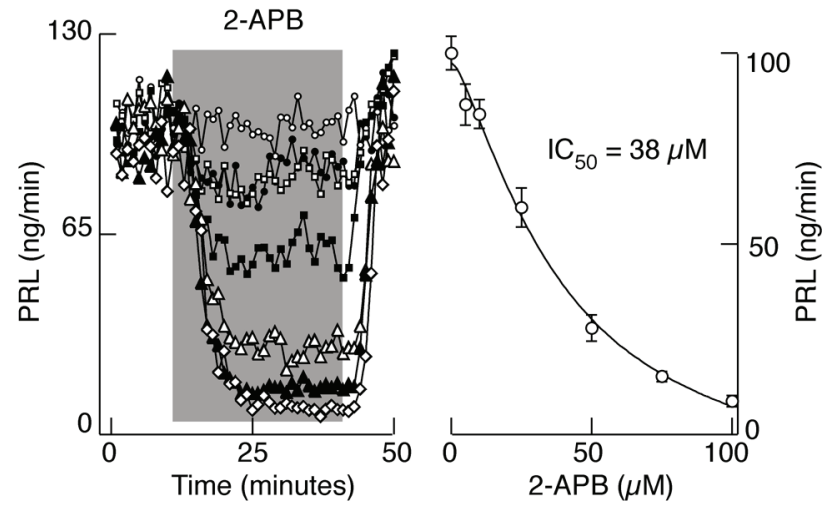

Fig. 4. Effects of specific blockers of TRPC channels on calcium influx and PRL release. A, Inhibition of spontaneous calcium influx by SKF96365 in lactotrophs. B, Dose-dependent effect of SKF96365 on basal PRL release. From top to bottom: 10, 25, $50 \mu$ M SKF96365. C, Dose-dependent effects of 2-APB on basal PRL release. Left, representative records in response to $0,5,10$, $25,50,75$ and $100 \mu \mathrm{M} 2-\mathrm{APB}$ (from top to bottom). Right, concentration-dependence study revealed the $\mathrm{IC}_{50}$ value of $38 \mu \mathrm{M}$. Mean \pm SEM values of four experiments are shown.

\section{Discussion}

Lactotrophs and $\mathrm{GH}_{3}$ cells fire APs spontaneously and such electrical activity drives 
transients in $\left[\mathrm{Ca}^{2+}\right]_{\mathrm{i}}$ (Van Goor et al. 2001a, Mollard et al. 1996, Schlegel et al. 1987) of sufficient amplitude to trigger PRL release (Zorec 1996). The role of bath $\mathrm{Ca}^{2+}$ and $\mathrm{Ca}_{\mathrm{v}}$ channels in both spontaneous firing of APs and basal PRL release is well established. Basal PRL release is abolished in cells with blocked $\mathrm{Ca}_{\mathrm{v}}$ channels, which are responsible for spike depolarization and the accompanied $\mathrm{Ca}^{2+}$ influx (Van Goor et al. 2001a). This is a unique characteristic of lactotrophs and somatotrophs; in other anterior pituitary cell types, spontaneous electrical activity does not cause significant hormone secretion (Stojilkovic et al. 1988).

In this study, we examined the role of bath $\mathrm{Na}^{+}$ in electrical activity, $\mathrm{Ca}^{2+}$ signaling and PRL release. We showed that replacement of bath $\mathrm{Na}^{+}$with large organic cations resulted in the membrane hyperpolarization and consequent abolition of spontaneous AP firing in pituitary lactotrophs and $\mathrm{GH}_{3}$ cells. Experiments with voltage-clamped cells at resting membrane potential further revealed that replacement of bath $\mathrm{Na}^{+}$with organic cations caused a loss of basal depolarizing conductance. The $\mathrm{Na}^{+}$conductance is TTX-insensitive, it determines the resting membrane potential, and is necessary for the spontaneous firing of $\mathrm{Ca}^{2+}$-dependent APs as well as the associated $\mathrm{Ca}^{2+}$ transients and PRL release. Others published similar observations in $\mathrm{GH}_{3}$ cells (Simasko 1994) and lactotrophs (Sankaranarayanan and Simasko 1996), and termed this conductance $\mathrm{Na}_{b}$ conductance. Its presence is not unique to PRL-secreting cells, but was also observed in other endocrine pituitary cells, including somatotrophs and gonadotrophs (Kucka et al. 2010). We have reported recently that $\mathrm{Na}_{b}$ conductance plays an important role in multidrugresistance protein-mediated cyclic nucleotide efflux in anterior pituitary cells (Kucka et al. 2010). However, the nature of the channels that enable this conductance and the mechanism for its activation has not been clarified.

Recently, we have also reported that $\mathrm{Na}_{b}$ conductance could be mediated by TRPC channels, the largest family of cation-conducting channels (Tomic et al. 2011). In general, their activation leads to $\mathrm{Na}^{+}$and $\mathrm{Ca}^{2+}$ influx and consequent depolarization of the plasma membrane (Clapham et al. 2005). Consistent with the role of $\mathrm{Na}_{b}$ current in the control of resting membrane potential in normal and immortalized pituitary cells, some
TRPC channels are constitutively active (Trebak et al. 2003, Nichols et al. 2007). Furthermore, TRPC4 was suggested as a molecular candidate for the nonselective cation channel responsible for the pacemaker activity in interstitial cells of Cajal (Kim et al. 2006). TRPC cation channels mediating persistent muscarinic currents also contribute significantly to the firing and mnemonic properties of projection neurons in the entorhinal cortex (Zhang et al. 2011). Leptin also depolarizes the plasma membrane via activation of TRPC channels in guinea pig kisspeptin neurons and proopiomelanocortin neurons (Qiu et al. 2010, Qui et al. 2011). These channels also contribute to agonist-induced depolarization of hypothalamic gonadotropin-releasing neurons (Zhang et al. 2008).

With such a tissue-wide distribution and involvement in electrical activity, here we give preliminary evidence for the further role of TRPC channels in $\mathrm{Na}_{b}$ conductance, $\mathrm{Ca}^{2+}$ signaling and hormone secretion of pituitary lactotrophs and $\mathrm{GH}_{3}$ lactosomatotrophs. The mRNA transcripts for TRPC1 channels are highly expressed in normal and immortalized pituitary cells, whereas the expression of other subunits of this family of channels is below $5 \%$ of TRPC1-mRNAs. The blockers of TRPC channels, SKF96365 and 2-APB, and the nonselective blockers of cation channels including TRPC channels, FFA and $\mathrm{Gd}^{3+}$, hyperpolarize the plasma membrane and inhibit spontaneous firing of APs, accompanied calcium influx and basal PRL release. Therefore, a TTX-resistant background-depolarizing $\mathrm{Na}^{+}$channels, presumably belonging to the TRPC family, are critical for firing of APs, accompanied $\mathrm{Ca}^{2+}$ influx, and PRL release in lactotrophs and $\mathrm{GH}_{3}$ cells.

\section{Conflict of Interest}

There is no conflict of interest.

\section{Acknowledgements}

The authors were supported by the Intramural Research Program of the National Institute of Child Health and Human Development, the Grant Agency of the Czech Republic (305/07/0681) and the Project Excellence (P304/12/G069).

\section{References}

BIAGI BA, ENYEART JJ: Gadolinium blocks low- and high-threshold calcium currents in pituitary cells. Am J Physiol 259: C515-C520, 1990. 
CLAPHAM DE, JULIUS D, MONTELL C, SCHULTZ G: International Union of Pharmacology XLIX. Nomenclature and structure-function relationships of transient receptor potential channels. Pharmacol Rev 57: 427-450, 2005.

CRONIN MJ, FAURE N, MARTIAL JA, WEINER RI: Absence of high affinity dopamine receptors in GH3 cells: a prolactin-secreting clone resistant to the inhibitory action of dopamine. Endocrinology 106: 718-723, 1980.

EGOROV AV, HAMAM BN, FRANSEN E, HASSELMO ME, ALONSO AA: Graded persistent activity in entorhinal cortex neurons. Nature 420: 173-178, 2002.

FREEMAN ME, KANYICSKA B, LERANT A, NAGY G: Prolactin: structure, function, and regulation of secretion. Physiol Rev 80: 1523-1631, 2000.

GHAMARI-LANGROUDI M, BOURQUE CW: Caesium blocks depolarizing after-potentials and phasic firing in rat supraoptic neurones. $J$ Physiol 545: 537-542, 2002.

KELBERMAN D, RIZZOTI K, LOVELL-BADGE R, ROBINSON IC, DATTANI MT: Genetic regulation of pituitary gland development in human and mouse. Endocr Rev 30: 790-829, 2009.

KIM BJ, SO I, KIM KW: The relationship of TRP channels to the pacemaker activity of interstitial cells of Cajal in the gastrointestinal tract. J Smooth Muscle Res 42: 1-7, 2006.

KUCKA M, KRETSCHMANNOVA K, MURANO T, WU CP, ZEMKOVA H, AMBUDKAR SV, STOJILKOVIC SS: Dependence of multidrug resistance protein-mediated cyclic nucleotide efflux on the background sodium conductance. Mol Pharmacol 77: 270-279, 2010.

KWIECIEN R, HAMMOND C: Differential management of $\mathrm{Ca}^{2+}$ oscillations by anterior pituitary cells: a comparative overview. Neuroendocrinology 68: 135-151, 1998.

LACAMPAGNE A, GANNIER F, ARGIBAY J, GARNIER D, LE GUENNEC JY: The stretch-activated ion channel blocker gadolinium also blocks L-type calcium channels in isolated ventricular myocytes of the guinea-pig. Biochim Biophys Acta 1191: 205-208, 1994.

LO YK, WU SN, LEE CT, LI HF, CHIANG HT: Characterization of action potential waveform-evoked L-type calcium currents in pituitary $\mathrm{GH}_{3}$ cells. Pflugers Arch 442: 547-557, 2001.

LUSSIER BT, FRENCH MB, MOOR BC, KRAICER J: Free intracellular $\mathrm{Ca}^{2+}$ concentration $\left(\left[\mathrm{Ca}^{2+}\right]_{\mathrm{i}}\right)$ and growth hormone release from purified rat somatotrophs. I. GH-releasing factor-induced $\mathrm{Ca}^{2+}$ influx raises $\left[\mathrm{Ca}^{2+}\right]_{\mathrm{i}}$. Endocrinology 128: 570-582, 1991.

MARIC D, SIMONOVIC I, KOVACEVIC R, KRSMANOVIC L, STOJILKOVIC SS, ANDJUS RK: Effects of shortterm and long-term hypeprolactinema on the developmental pattern of androgen and LH levels in the immature male rats. J Endocrinol Invest 5: 235-241, 1982.

MISSALE C, NASH SR, ROBINSON SW, JABER M, CARON MG: Dopamine receptors: from structure to function. Physiol Rev 78: 189-225, 1998.

MOLLARD P, SCHLEGEL W: Why are endocrine pituitary cells excitable? Trends Endocrinol Metab 7: 361-365, 1996.

NICHOLS RA, DENGLER AF, NAKAGAWA EM, BASHKIN M, PAUL BT, WU J, KHAN GM: A constitutive, transient receptor potential-like $\mathrm{Ca}^{2+}$ influx pathway in presynaptic nerve endings independent of voltage-gated $\mathrm{Ca}^{2+}$ channels and $\mathrm{Na}^{+} / \mathrm{Ca}^{2+}$ exchange. J Biol Chem 282: 36102-36111, 2007.

QIU J, FANG Y, BOSCH MA, RONNEKLEIV OK, KELLY MJ: Guinea pig kisspeptin neurons are depolarized by leptin via activation of TRPC channels. Endocrinology 152: 1503-1514, 2011.

QIU J, FANG Y, RONNEKLEIV OK, KELLY MJ: Leptin excites proopiomelanocortin neurons via activation of TRPC channels. J Neurosci 30: 1560-1565, 2010.

SANKARANARAYANAN S, SIMASKO SM: A role for a background sodium current in spontaneous action potentials and secretion from rat lactotrophs. Am J Physiol 271: C1927-C1934, 1996.

SCHLEGEL W, WINIGER BP, MOLLARD P, VACHER P, WUARIN F, ZAHND GR, WOLLHEIM CB, DUFY B: Oscillations of cytosolic $\mathrm{Ca}^{2+}$ in pituitary cells due to action potentials. Nature 329: 719-721, 1987.

SIMASKO SM: A background sodium conductance is necessary for spontaneous depolarizations in rat pituitary cell line $\mathrm{GH}_{3}$. Am J Physiol 266: C709-C719, 1994.

STOJILKOVIC SS, IZUMI S, CATT KJ: Participation of voltage-sensitive calcium channels in pituitary hormone release. J Biol Chem 263: 13054-13061, 1988. 
STOJILKOVIC SS, TABAK J, BERTRAM R: Ion channels and signaling in the pituitary gland. Endocr Rev 31: 845915, 2010.

STOJILKOVIC SS, ZEMKOVA H, VAN GOOR F: Biophysical basis of pituitary cell type-specific $\mathrm{Ca}^{2+}$ signalingsecretion coupling. Trends Endocrinol Metab 16: 152-159, 2005.

TOMIC M, KUCKA M, KRETSCHMANNOVA K, LI S, NESTEROVA M, STRATAKIS CA, STOJILKOVIC SS: Role of nonselective cation channels in spontaneous and protein kinase A-stimulated calcium signaling in pituitary cells. Am J Physiol Endocrinol Metab 301: E370-E379, 2011.

TREBAK M, VAZQUEZ G, BIRD GS, PUTNEY JW Jr: The TRPC3/6/7 subfamily of cation channels. Cell Calcium 33: 451-461, 2003.

TSANEVA-ATANASOVA K, SHERMAN A, VAN GOOR F, STOJILKOVIC SS: Mechanism of spontaneous and receptor-controlled electrical activity in pituitary somatotrophs: experiments and theory. $J$ Neurophysiol $\mathbf{9 8}$ : 131-144, 2007.

VAN GOOR F, ZIVADINOVIC D, MARTINEZ-FUENTES AJ, STOJILKOVIC SS: Dependence of pituitary hormone secretion on the pattern of spontaneous voltage-gated calcium influx. Cell type-specific action potential secretion coupling. J Biol Chem 276: 33840-33846, 2001a.

VAN GOOR F, ZIVADINOVIC D, STOJILKOVIC SS: Differential expression of ionic channels in rat anterior pituitary cells. Mol Endocrinol 15: 1222-1236, 2001b.

ZHANG C, ROEPKE TA, KELLY MJ, RONNEKLEIV OK: Kisspeptin depolarizes gonadotropin releasing hormone neurons through activation of TRPC-like cationic channels. J Neurosci 28: 4423-4434, 2008.

ZHANG Z, REBOREDA A, ALONSO A, BARKER PA, SEGUELA P: TRPC channels underlie cholinergic plateau potentials and persistent activity in entorhinal cortex. Hippocampus 21: 386-397, 2011.

ZOREC R: Calcium signaling and secretion in pituitary cells. Trends Endocrinol Metab 7: 384-388, 1996. 